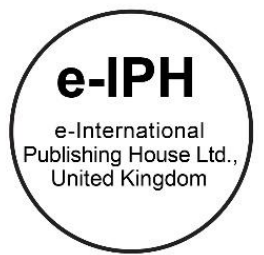

\title{
Well-Being Assessment of Youth in Urban Marginalized Community
}

\author{
Saberi Othman ${ }^{* 1}$, Mohd Mohni Iskandar² ${ }^{2}$ Nur Ikhwan Mohamed² \\ ${ }^{1}$ Department of biology, Faculty of science and Mathematics, UUniersiti Pendidikan Sultan Idris, $35900 \mathrm{Tg}$ Malim, Perak, Malaysia \\ ${ }^{2}$ Faculty of Sport Science and Coaching, UPSI
}

\begin{abstract}
This paper examines the well-being of eight domains of youth in the marginalized urban community. Study area was at Low Cost Housing Project of Lembah Pantai, Kuala Lumpur. Four hundred of youth age between $15-25$ years old has been selected by stratified sampling. The average of well-being score is intermediate for the whole sample. However, the male score is slightly higher compared to female. Moral values show the highest score whilst participation in the community shows the lowest score for both male and female. As a conclusion, there is intermediate score of well-being of youth in the urban marginalized community.

(c) 2016. The Authors. Published for AMER ABRA by e-International Publishing House, Ltd., UK. This is an open access article under the CC BY-NC-ND license (http://creativecommons.org/licenses/by-nc-nd/4.0/).

Peer-review under responsibility of AMER (Association of Malaysian Environment-Behaviour Researchers), ABRA (Association of Behavioural Researchers on Asians) and CE-Bs (Centre for Environment-Behaviour Studies), Faculty of Architecture, Planning \& Surveying, Universiti Teknologi MARA, Malaysia.
\end{abstract}

Keywords: Well-being; marginalized; community; youth

\section{Introduction}

Youth constitutes almost half of the Malaysian population. Asnarulkhadi (2009) stated that youth is positively influential towards nation building whether from political (voters), social (unity), or economy (human capital) aspects. The youths in Malaysia must be developed as homo intelligence youth which is the generation of post-modern knowledge era, have high personality, smart in using knowledge for life-long improvement and contribute to development of society and nation (Jalaluddin, 2009). Delgado (2002) stated that positive youth development aims to identify youth needs and cultivate relevant competency towards producing successful adult generation. Compared to the approach of seeing youth as problematic group, positive youth approach, on the other hand, see this group as sources and develop based from their strength and ability, nurtured in their own community (Delgado, 2002). Although youth in Malaysia is define as group of people's age between 15 to 40, but in this study youth is defined as the group young people's aged between $15-25$, within the range proposed by UNESCO $15-24$ years of age (UNESCO, 2001).

\footnotetext{
* Corresponding author. Tel.:

E-mail addres: saberi@fsmt.upsi.edu.my
}

2398-4287 @ 2016. The Authors. Published for AMER ABRA by e-International Publishing House, Ltd., UK. This is an open access article under the CC BY-NC-ND license (http://creativecommons.org/licenses/by-nc-nd/4.0/).

Peer-review under responsibility of AMER (Association of Malaysian Environment-Behaviour Researchers), ABRA (Association of Behavioural Researchers on Asians) and CE-Bs (Centre for Environment-Behaviour Studies), Faculty of Architecture, Planning \& Surveying, Universiti Teknologi MARA, Malaysia.

DOI: http://dx.doi.org/10.21834/e-bpj.v1i3.349 
Not all youth have the same opportunity and privilege, because substantial numbers of youth live in marginalized community, a community that's confined to the lower or peripheral edge of the society. Such a community has little opportunities to get involve in mainstream economic, political, cultural and social activities. It denies a section of the society equal access to productive resources and avenues for the realization of their productive human potential and opportunities for their full capacity utilization of their maximum potential for prosperity.

In urban area, a community may be marginalized due to low family income, consequently they are denies to get better accommodation, public amenities and other facilities that could improve their socio-economic standing. In Malaysia, living in a big city such as Kuala Lumpur, family income less than RM 3,000 per month categorized as urban poor because they have to deal with high cost of living due to high prices of goods, houses, rented houses, apartments, education, and transportation. They can't afford to live in conducive apartment or houses, thus depriving them from good living condition such as family gathering, togetherness and other family activities They have no choice, to live in low cost apartments or houses, area lacking or shortage of public amenities such as sport facilities namely football field, badminton court, volley ball, basket ball, futsal and gymnasium. To rent the sport facilities outside the community will cost them substantial amount of money.

Where ever they live, marginalized or non-marginalized community, youth is a crucial period for establishing positive health and social behaviors. It is a time when young people are undergoing rapid emotional, physical and intellectual changes, and when they begin the transition from childhood to adolescence to independent adulthood. Thus, it is timely, comprehensive information on the wellbeing of youth is therefore essential for monitoring the progress of Malaysia's youth. Thus the objective of this paper is to assess the well-being of youth in a marginalized community in Malaysia. Well-being of youth is measured subjectively through individual's perception of their happiness with different aspects of indicators, which have been discussed by several authors (e.g. Cummins et al., 2003; Diener et al., 1999; van Hoorn, 2006).

\section{Methodology}

\subsection{Study area}

Study was conducted at low cost housing area (apartment) of Lembah Pantai,(Pantai Valley) in the city of Kuala Lumpur. This housing area categorized by Kuala Lumpur Centre as Housing Project for public with income less than RM 3,000 per month. Study area was selected based on the Focus Group Discussion (FGD) for youth from selected area in Kuala Lumpur. From FGD data it shows that community of housing area (low cost apartment) at Lembah Pantai have many occupants with family income less than RM 3,000. The area consists of four blocks of apartment, each block has 17 floors and each floor consist of 20 apartments.

\subsection{Participants}

Participants were determined by the following procedure. Two floors of each block were clustered and 14 participants from those floors were choosing randomly. Each block was represented by 112 participants, and 448 for four blocks. Participants were given questionnaire consisting of two sections. Section A questionnaire for demographic (Section A), and Section B questionnaire for well-being. There were 224 males and 176 female youth responded and answered all the questions. 


\subsection{Questionnaire}

Questionnaire for demographic (Section A) include type of accommodation, location of accommodation, age, ethnic group, religion, and level of education, number of persons occupying the accommodation, jobs, and monthly income. Based on the literature review, indicators for well-being questionnaire (Section B) identified as the standard of living, health, physical activity, emotion, security, youth participation in the community, future hope and moral values (e.g. Cummins et al., 2012; Tomyn and Cummins, 2010; Tomyn et al., 2011). Items were rated from 1 to 5 scale, similar scale have been used by authors such as Tennant et al. (2007), Deci et al. (2001), Gagne (2003) and Ryan and Frederick (1997). Scale data then were converted to percentage. Rating $80 \%$ and above considered high, 51 to 79 intermediate, while 50 and below considered low. All questionnaires then were analyzed by SPSS. The alpha coefficient for the eight items is .874 , suggesting that the items have relatively high internal consistency, because a reliability coefficient of .70 or higher is considered acceptable in most social science research situations (e.g. Cortina, 1993; Tavakol and Dennick, 2011).

\section{Results}

\subsection{Data cleaning and preparation}

All cases were examined for response questionnaires set. Participants that consistently scored minimum (1) or maximum (5) for all eight domains considered unreliable and removed from the analysis. At the end the number of reliable answered questionnaire set was 400 (224 male and 176 female).

\subsection{Demography}

Table 1. shows the number of male and female of the participants and age group analysis. Among 400 participants involved in the study, 224 (56.1) were male and 176 (43.9\%) were female. Age group of $15-17$ and $21-23$ years old $31.5 \%$ and $32.75 \%$ higher compared to age group of $18-20(18.5 \%)$ and $24-25(14.75 \%)$.

Table 1. Gender analysis and age group of participants

\begin{tabular}{cccc}
\hline & & $\mathrm{n}$ & Percentage $(\%)$ \\
\hline \multirow{3}{*}{ Gender } & Male & 224 & 56.10 \\
& Female & 176 & 43.90 \\
\hline \multirow{3}{*}{ Age group } & $15-17$ & 125 & 31.50 \\
& $18-20$ & 84 & 18.50 \\
& $21-23$ & 131 & 32.75 \\
& $24-25$ & 59 & 14.75 \\
\hline
\end{tabular}

High percentage of the participants having low education level, and only $26.2 \%$ of them have the opportunity to go higher level of education (12.5\% Diploma, and 13.7\% university graduate) (Table 2). Low level of education of the participants reflected in their monthly income. About $17.5 \%$ earned less than MYR 500 per month, while about $39 \%$ earned between MYR 501 to RM 3000 per month (Table 3). However, about 1\% of the participants earned between 
MYR 3001 to > MYR 4,000 per months. Most family has income and only 15\% (57) earned more than RM 3501 per month. Participants with no income were students.

Table 2. Analysis of the education level of the participants

\begin{tabular}{ccc}
\hline Education Level & $\mathrm{n}$ & Percentage (\%) \\
\hline Primary school (Standard 6) & 14 & 3.5 \\
Lower secondary (form 3) & 73 & 18.2 \\
Upper secondary (form 5) & 162 & 40.4 \\
Upper secondary (form 6) & 37 & 9.2 \\
Certificate & 10 & 2.5 \\
Diploma & 50 & 12.5 \\
Degree & 54 & 13.7 \\
\hline
\end{tabular}

Type of accommodation at the study area having floor size of $700 \mathrm{sq} \mathrm{ft}$, comfortable for 3 family members. However, $55.7 \%$ of the houses occupied by family members more than 3 (4-6 family members), $27.7 \%$ occupied by $7-9$ family members (Table 4). A number of houses shared by bachelors of $10-14$ peoples (7.9\%). A number of FGD participants admit that sharing house may be uncomfortable, but it can save money. A number of houses also shared by more than one family; 2 families $3.5 \%, 3$ families $2.0 \%$ and 4 families $5.7 \%$.

Table 3. Monthly Income of Participants and their families

\begin{tabular}{lcccc}
\hline \multicolumn{2}{c}{ Income group (MYR) } & \multicolumn{2}{c}{ Participants } & \multicolumn{2}{c}{ Family } \\
\hline & $n$ & $\begin{array}{c}\text { Percentage } \\
(\%)\end{array}$ & $n$ & $\begin{array}{c}\text { Percentage } \\
(\%)\end{array}$ \\
\cline { 2 - 5 } No income & 168 & 42.1 & - & - \\
$<500$ & 70 & 17.5 & 29 & 7.2 \\
$501-1000$ & 56 & 14.0 & 42 & 10.5 \\
$1001-1500$ & 54 & 13.5 & 60 & 15.0 \\
$1501-2000$ & 33 & 8.2 & 66 & 16.5 \\
$2001-2500$ & 11 & 2.7 & 65 & 16.2 \\
$2501-3000$ & 4 & 1.0 & 51 & 12.7 \\
$3001-3500$ & 2 & 0.5 & 30 & 7.5 \\
$3501-4000$ & 1 & 0.25 & 16 & 4.0 \\
$>4000$ & 1 & 0.25 & 41 & 10.5 \\
\hline
\end{tabular}

Table 4. Number of family and family members live in the house

\begin{tabular}{cccccc}
\hline \multicolumn{3}{c}{ Family members } & & No of family & \\
\hline Family members & $\mathrm{n}$ & $\begin{array}{c}\text { Percentage } \\
(\%)\end{array}$ & No of family & $\mathrm{n}$ & $\begin{array}{c}\text { Percentage } \\
(\%)\end{array}$ \\
\hline $1-3$ & 35 & 8.7 & 1 & 355 & 88.8 \\
$4-6$ & 222 & 55.7 & 2 & 14 & 3.5 \\
$7-9$ & 111 & 27.7 & 3 & 8 & 2.0 \\
$10-14$ & 32 & 7.9 & 4 & 23 & 5.7 \\
\hline
\end{tabular}


High percentage of the participants live with families (85\%), the others live with relatives or friends (Table 5).

Table 5. With whom the participants live and houses they live in

\begin{tabular}{cccccc}
\hline \multicolumn{2}{c}{ With whom the participants live } & \multicolumn{2}{c}{ Houses the participants live in } \\
\hline Live with & $\mathrm{n}$ & $\begin{array}{c}\text { Percentage } \\
(\%)\end{array}$ & Whose house & $\mathrm{n}$ & $\begin{array}{c}\text { Percentage } \\
(\%)\end{array}$ \\
\hline Alone & 14 & 3.5 & Own house & 5 & 1.3 \\
Family & 340 & 85.0 & Family & 221 & 55.1 \\
Relatives & 9 & 2.2 & rented & 174 & 46.6 \\
Friends & 37 & 9.3 & & & \\
\hline
\end{tabular}

Only small percentage (3.5\%) lives alone. About $46.6 \%$ live in rented house. Motorcycles and motorcars are type of vehicles owned by participants and their families (Table 6). However, $44.1 \%$ of the participant relied on public transport or family vehicles because they do not own vehicles. About $4.8 \%$ of the families also do not owned any type of vehicles.

About $33.4 \%$ are employed (Table 7). Those unemployed can be divided into two categories; unemployed but not active seeking jobs about $4.5 \%$, and unemployed but actively seeking jobs (2.5\%). High percentage of the participants was students.

Table 6. Type of vehicles owned by the participants and family

\begin{tabular}{lcccc}
\hline \multicolumn{1}{c}{ Type of vehicles } & \multicolumn{2}{c}{ Participants } & \multicolumn{2}{c}{ Family } \\
\hline & $\mathrm{n}$ & $\begin{array}{c}\text { Percentage } \\
(\%)\end{array}$ & $\mathrm{n}$ & $\begin{array}{c}\text { Percentage } \\
(\%)\end{array}$ \\
\hline Bicycles & 14 & 3.5 & 5 & 1.2 \\
Motorcycles & 161 & 40.1 & 76 & 19.2 \\
Cars & 49 & 12.3 & 300 & 74.8 \\
None & 176 & 44.1 & 19 & 4.8 \\
\hline
\end{tabular}

Table 7. Employment status of the participants

\begin{tabular}{lcc}
\hline \multicolumn{1}{c}{ Employment status } & $\mathrm{n}$ & Percentage (\%) \\
\hline Employed & 134 & 33.4 \\
Unemployed (non active) & 18 & 4.5 \\
Unemployed (active) & 10 & 2.5 \\
Unemployed (students) & 239 & 59.6 \\
\hline
\end{tabular}




\subsection{Well-being assessment}

Results of the study focus on the well-being rating of youth in the marginalized community, and explain according to gender both descriptive and inferential statistics. Table 8 shows well-being rating for the whole samples and between genders of youth at Lembah Pantai. Majority of the samples is in the intermediate rating, and none in the high rating suggesting that youth in this marginalized community perceived moderate well-being category. They satisfy with their moral values shown by the highest percentage. The lowest score of well being rating is youth participation in the community activity, suggesting that they are not well adapted to community or choose to stay away from the activity.

The well-being rating between male and female youth do not differ much, but percentage for male slightly higher compared to female. Analysis between gender showed that male is significantly have positive perception on standard of living $(P=0.0088,<0.05)$, and perception on health $(P=0.0240,<0.05)$. The rest of the well-being rating does not significantly difference between male and female.

Statistical analysis shows that Kaiser-Meyer-Olkin measures of sampling adequacy at value of 0.907 suggesting superb values (Kaiser, 1974; Hutcheson and Sofroniou, 1999; Field, 2005), thus factor analysis is appropriate for this data. Correlation matrix of the well-being items is presented in Table 9. Correlation matrix of factor analysis shows that standard of living is significantly correlated with health, physical activity, youth participation and future hope. While physical activity also significantly correlated with health, emotion and safety. In conclusion, assessment of adolescence in the marginalized urban community, shows an intermediate rating of well-being, however, the participation of youth in the community activity shows the lowest rating compare to the other factors.

Table 8. Well-being rating by gender of youth at Lembah Pantai, Kuala Lumpur

\begin{tabular}{|l|c|c|c|c|c|c|c|}
\hline \multirow{2}{*}{ Well-being domains } & \multicolumn{2}{|c|}{ All Samples $(\mathrm{n}=400)$} & \multicolumn{2}{c|}{ Male $(\mathrm{n}=224)$} & \multicolumn{2}{c|}{ Female $(\mathrm{n}=176)$} & \\
\hline & M1 & SD & M2 & SD & M3 & SD & M2 - M3 \\
\hline Standard of living & 73.50 & 21.20 & 75.00 & 21.00 & 72.14 & 21.42 & 2.86 \\
\hline Health & 73.81 & 22.11 & 76.89 & 19.60 & 69.86 & 24.46 & 7.03 \\
\hline Physical activity & 73.50 & 22.20 & 75.22 & 21.26 & 71.29 & 23.22 & 3.93 \\
\hline Emotion & 71.75 & 23.12 & 72.56 & 22.90 & 70.71 & 23.43 & 1.85 \\
\hline Safety & 70.69 & 24.70 & 71.44 & 25.41 & 69.71 & 23.80 & 1.73 \\
\hline Youth participation in community activity & 68.88 & 23.15 & 71.33 & 21.53 & 65.71 & 24.80 & 5.62 \\
\hline Future hope & 74.38 & 23.21 & 74.78 & 23.02 & 73.86 & 23.50 & 0.92 \\
\hline Moral values & 75.69 & 23.17 & 77.78 & 21.54 & 73.00 & 25.00 & 4.78 \\
\hline \multicolumn{1}{|c|}{ Mean } & 72.93 & 17.03 & 74.57 & 15.39 & 70.80 & 18.80 & \\
\hline
\end{tabular}

Table 9. Correlation matrix between well-being items

\begin{tabular}{ccccccccc}
\hline $\begin{array}{c}\text { Well- } \\
\text { being }\end{array}$ & 1 & 2 & 3 & 4 & 5 & 6 & 7 & 8 \\
items & & & & & & & & \\
1 & - & & & & & & & \\
2 & $.508^{* * *}$ & - & & & & & \\
3 & $.520^{* * *}$ & $.608^{* * *}$ & - & & & & \\
\hline
\end{tabular}




\begin{tabular}{|c|c|c|c|c|c|c|c|c|}
\hline 4 & .449 & $.544^{* * *}$ & $.516^{\star * \star}$ & - & & & & \\
\hline 5 & .408 & $.528^{\star * *}$ & .484 & .494 & - & & & \\
\hline 6 & $.501^{* * *}$ & .435 & .486 & .458 & $.535^{\star \star *}$ & - & & \\
\hline 7 & $.524^{* * *}$ & .424 & .485 & .433 & .478 & $.586^{\star * *}$ & - & \\
\hline 8 & .481 & .405 & .443 & .422 & .473 & $.532^{* \star *}$ & $.661^{* * *}$ & - \\
\hline
\end{tabular}

Notes: ${ }^{* * *}$ Sig. at 0.001

Notes: 1 - Standard of living; 2 - Health; 3 - Physical activity; 4 - Emotion; 5 - Safety

6 - Youth participation in community activity; 7 - Future hope; 8 - Moral values

\section{Discussion}

Several well-being studies have been conducted in Malaysia especially on woman participation in economic activities (Noraini M. Noor, 1999, 2002, 2003, 2004; Aminah Ahmad (1996), and Hilla and King (1995); family conflict and genders (e.g. Kinnunenab et al., 2004); report on youth in Malaysia (United Nation, 2002). However, not many studies on well-being of youth in the marginalized community. This study focus on the youth in the marginalized community in Lembah Pantai, Kuala Lumpur, Malaysia.

The cost-of-living is typically higher in big cities such as Kuala Lumpur. You need good job to earn good living and it can cost substantial amount of money. To get good job you need good academic qualification. Demographic study of Lembah Pantai area shows that, many of the youth still without job but they are not active in seeking job, probably they are not confident of themselves, demotivated (e.g. Coeli, 1978) or very dependent on their parents. The other reasons they are do not qualify, due to low academic qualification make them shy away from job market.

The well-being rating of youth in this marginalized community do not reflect their demography (e.g. Bianchi et al., 1999). Most of well-being rating score intermediate, suggesting they are satisfy with their moderate lives. However, well-being rating on participation of youth in the community activity shows the lowest for both genders. Understanding the youth is an important process in order to involve them in the community activity and development. An understanding of youth motivations and efficacy are important so that extension and other development professionals can maximize these valuable resources (e.g. Brennan et al., 2007).

Although they live in the marginalized community, Lembah Pantai is close to convenience of public transportation, entertainment options, window shopping, social events, medical care, and sports. These factors influenced the perception of life and give rating of well-being score intermediate.

Well-being rating for security and future hope make female youth worry which discussed during FGD with group of youth. Security around the lift, stairs and pavements around the community area have been said not too secure for female especially at night. The insecurity for female is reflected in their well-being rating.

\section{Conclusions and Recommendations}

In conclusion well-being Index of youth in urban marginalized community of Lembah Pantai, Kuala Lumpur showed at the intermediate level. However, well-being rating on participation of youth in the community activity shows the lowest for both genders. There is no significant different between male and female, except female respondents feel insecure around their environment. Thus, this study recommends the authority to plan more suitable activities in the future to ensure involvement, engagement and participation of youth as part of the community members. This study also recommends the authority to increase security measure around community area such as providing more lighting especially at pedestrian walk away and closed-circuit TV in the lift. 


\section{Acknowledgement}

I would to express my word of thanks to Ministry of Higher Learning, for allowing me to use research grant, Long Term Research Grant Scheme (LRGS), and Universiti Pendidikan Sultan Idris for me to attend the conference.

\section{References}

Aminah Ahmad (1996). Work-Family Conflict Among Married Professional Women in Malaysia. The Journal of Social Psychology Volume 136, Issue 5, 663-665.

Brennan, M. A., Rosemary V. Barnett and Eboni Baugh (2007). Youth Involvement in Community Development: Implications and Possibilities for Extension. Extension Journal Vol. 45, No. 4, 319-326).

Bianchi, S. M, Subaiya, L. and Kahn, J. R. (1999). The gender gap in the economic well-being of nonresident fathers and custodial mothers. Demography, Volume 36, Issue 2, pp 195-20.

Cortina, J.M. (1993). What is coefficient alpha? An examination of theory and applications. Journal of Applied Psychology, Vol 78(1), 98-104.

Cummins, R. A., Eckersley, R., Pallant, J., van Vugt, J. V., \& Misajon, R. (2003). Developing a national index of subjective wellbeing: The Australian Unity Well-being Index. Social Indicators Research, 64,159-190.

Cummins, R.A., Woerner, J., Weinberg, M.,Collard, J., Hartley-Clark, L.,Perera, C., and Horfiniak, K. (2012). The Wellbeing of Australians Quantity and Quality of Sleep. Australian Unity Wellbeing Index Report 27.0. Australian Centre on Quality of Life Deakin University, 221 Burwood Highway Melbourne, Victoria 3125, Australia

Diener, E., Suh, M., Lucas, E., \& Smith, H. (1999). Subjective well-being: Three decades of progress. Psychological Bulletin, 125, $276-302$.

Deci, E. L., Ryan, R. M., Gagné, M., Leone, D. R., Usunov, J and Kornazheva, B. J. (2001). Need Satisfaction, Motivation, and Well-Being in the Work Organizations of a Former Eastern Bloc Country: A Cross-Cultural Study of Self-Determination. Pers Soc Psychol Bull August 2001 vol. 27 no. $8930-942$

Field, A. P. (2005). Discovering Statistics Using SPSS (2nd. Ed.). London. Sage Publication

Gagne, M. (2003). Autonomy Support and Need Satisfaction in the Motivation and Well-Being of Gymnasts. Journal of Applied Sport Psychology,Volume 15, Issue 4, 372-390.

Hutcheson G., \& Sofroniou N. (1999). The multivariate social scientist: introductory statistics using generalized linear models. London:Sage Publication

Hilla, M. A. and Elizabeth King, E. (1995). Women's education and economic well-being. Feminist Economics Volume 1, Issue 2, 21 - 46.

Kaiser, H.F. (1974). An index of factorial simplicity. Psychometrika, 39, 31-36.

Kinnunenab, U., Geurtsb, S. and Maunoa, S. (2004). Work-to-family conflict and its relationship with satisfaction and well-being: a one-year longitudinal study on gender differences. Work \& Stress: An International Journal of Work, Health \& Organizations Volume 18, Issue 1, 1- 22.

Meyer, M. C. (1978). Demotivation--Its Cause and Cure. Personnel Journal, 57, 5, 260-6.

Noraini M Noor (2004). Work-Family Conflict, Work- and Family-Role Salience, and Women's Well-Being. The Journal of Social Psychology Volume 144 , Issue 4, $389-406$.

Noraini M Noor (2002). Work-Family Conflict, Locus of Control, and Women's Weil-Being: Tests of Alternative Pathways. The Journal of Social Psychology Volume 142, Issue 5, 645 - 662.

Noraini M Noor (2003). Work- and family-related variables, work-family conflict and women's well-being: some observations. Community, Work \& Family Volume 6, Issue 3, $297-319$

Noraini M Noor (1999). Roles and woman's well-being: Some preliminary findings in Malaysia. Sex Roles ol. 14, No 314, 123 -145

Ryan, R. M. and Frederick, C. (1997). On Energy, Personality, and Health: Subjective Vitality as a Dynamic Reflection of Well-Being. Journal of Personality Volume 65, Issue 3, pages 529-565. 
Tavakol, M. and Dennick, R. (2011). Making sense of Cronbach's alpha. Int J Med Educ. 2: 53-55.

Tennant, R., Hiller, L., Fishwick, R., Platt, S., Joseph, S., Weich, S. Parkinson, J., Secker, J. and Stewart-Brown, S. (2007). The WarwickEdinburgh Mental Well-being Scale (WEMWBS): development and UK validation. Health and Quality of Life Outcomes 20075:63

Tomyn, A. J. and Cummins, R. A. (2011). The Subjective Wellbeing of High-School Students: Validating the Personal Wellbeing Index-School Children. Soc Indic Res.

United Nation (2002). YOUTH IN MALAYSIA: A Review of the Youth Situation and National Policies and Programmes. Economic and Social Commission for Asia and the Pacific. United Nation, New York.

UNESCO (2001). Assembly resolution A/RES/56/117.

van Hoorn, A. (2006). A short introduction to subjective well-being: Its measurement, correlates and policy uses. Retrieved February 24, 2016. From

http://www.oecd.org/dataoecd/16/39/38331839.pdf 